\title{
A Comparison of Students' Performances Using Audio Only and Video Media Methods
}

\author{
Norazean Sulaiman ${ }^{1}$, Ahmad Mazli Muhammad ${ }^{1}$, Nurul Nadiah Dewi Faizul Ganapathy ${ }^{1}$, \\ Zulaikha Khairuddin $^{1} \&$ Salwa Othman ${ }^{1}$ \\ ${ }^{1}$ Akademi Pengajian Bahasa, Universiti Teknologi MARA, Selangor, Malaysia \\ Correspondence: Zulaikha Khairuddin, Akademi Pengajian Bahasa, Universiti Teknologi MARA, Selangor, \\ Malaysia. E-mail: zulaikhakhairuddin@gmail.com
}

Received: April 19, 2017 Accepted: June 9, 2017 Online Published: June 12, 2017

doi: 10.5539/elt.v10n7p210 URL: http://doi.org/10.5539/elt.v10n7p210

\begin{abstract}
Listening is a very crucial skill to be learnt in second language classroom because it is essential for the development of spoken language proficiency (Hamouda, 2013). The aim of this study is to investigate the significant differences in terms of students' performance when using traditional (audio-only) method and video media method. The data of this study were collected by giving students the same two sets of questions in pre-test and post-test. The data were then analysed with paired-sample t-test by using Statistical Package for the Social Sciences (SPSS). Based on the results attained, it was found that the majority of the students obtained higher marks when using video media method compared to audio only method. Hence, it is recognised that by using video as one of the assessment tools will help students to perform better due to the use of authentic, meaningful and real-life situation contexts and language. Therefore, instructors are advised to use more authentic texts and materials when it comes to teaching and assessing listening skills in second language (L2) classroom.
\end{abstract}

Keywords: students' performance, listening assessment method, audio only, video media

\section{Introduction}

Listening skills are vital to be learnt in second language classroom and necessary for the development of spoken language proficiency (Hamouda, 2013). Previously, there were a lot of research done on the second language (L2) teaching, learning and testing of listening skills in the academia (Macwan, 2015; Richards \& Dolati, 2011; Meskill, 1996; Kenning \& Kenning, 1984). This is because listening is considered as a complex and active process whereby listeners need to discriminate various elements of vocabulary and grammatical structures, sounds, as well as stress and intonation simultaneously (Vandergrift, 1999).

\subsection{Problem Statement}

A research has been conducted to Diploma level students of University M undergoing English proficiency course that focuses on listening skills. This compulsory course is designed to equip students with the necessary tools for communicative competence. Currently, in University M, it was found that minority of students did not perform well in their listening assessment. Based on the lecturers' observation, this minority group was found to have difficulties in learning and using the language as they have failed in their English proficiency tests. On top of that, they have to enroll in the course several times. Hence, instructors were thinking that students need some scaffolding and help in order for them to answer the listening questions.

One of the ways to help these students is by showing them videos. This is because some students said that they would understand better if visual elements are incorporated in the assessment. To further instigate the root of the problem, VAK questionnaire has been distributed to identify the students' learning styles. It was found that the majority of the students were visual and kinaesthetic learners while only a minority of them was auditory learners. Hence, this study was conducted to investigate the differences in students' performance using different listening assessment methods as well as to provide the basis of understanding on the obstacles that hinder these students from performing well in the (L2) learning especially in the focus area of listening.

\subsection{Research Question}

Is there a significant difference in students' performances based on different assessment methods (video and 
audio) in listening assessment?

\section{Literature Review}

\subsection{Listening Assessment}

Listening is considered as a complex and active process whereby listeners need to discriminate various elements of vocabulary and grammatical structures, sounds, as well as stress and intonation (Vandergrift, 1999). He noted that listening involves the gathering of all the mentioned elements and interpreting it within an immediate and large sociocultural context of utterance. Listening is indeed a hard work that needs more analysis and support in which many researchers have come to agree with this point (LaScotte, 2015; Siegel, 2015; Yousefinia, 2012). Due to the challenges faced, many students struggle to thrive in this particular language skill. As a matter of fact, wrong methods were mistakenly chosen by some students in order for them to listen effectively upon completing a listening task that later led them to devastating results.

With a foundation that learners' perceptions of their listening problems and strategies can affect their comprehension both positively and negatively (Wenden, 1986), many researchers have come up with ways to help fortify students' listening skills. Some of the instructors believed that exposing students with audio material repeatedly in which also known as traditional method is less applicable to present days as the advance of technology has long been embodied to the lives of the students of the new generation (Kirana, 2016, Arono, 2014; Richards \& Dolati, 2011; Meskill, 1996). The listening assessment nowadays is sometimes accompanied with video material which is also recognised as a new media input method (Armium \& Rahmatian, 2011). The differences occurred in using different listening assessment methods to test listening skill and ability of the students are further highlighted in this paper.

\subsection{Traditional Method in Listening Assessment}

Traditionally, there are many effective methods used to teach listening skills which are still being used today.. Complex problems in listening process could easily and emotionally be explained with logical reasoning, hence, cannot be replaced with any modern technology these days (Wang \& Liu, 2013). Good results could be obtained in developing hearing ability when the traditional approach to an 'all purpose' pedagogical recorded text was given, however, it is not well revised in developing global understanding of spoken communications (The British Council, 1981). Improved confidence level among learners, especially for the less proficient ones were the results of combining traditional listening activities with post-listening reflections and discussions of metacognitive strategies for listening (Goh \& Taib, 2006). Likewise, Vandergrift and Tafaghodtari (2010) found that there are no explicit strategies for metacognitive instruction programme for listening. However, there is a guided practice on the listening process as a whole which further develop implicit knowledge about L2 listening through task performance which has improved listening scores for lower proficiency learners.

In the meantime, based on the study led by Başal, Gülözer and Demir (2015) and Londe (2009), no significant differences were found in regards to performance between three groups; two video formats and one audio-only format (close-up of the lecturer's face and full body view of the lecturer). Comparably, Gruba (1993) found no significant differences between video and audio-only groups in terms of performance. Moreover, studies done by Ockey (2007) and Bejar, Douglas, Jamieson, Nissan, and Turner (2000), showed that the use of video did not help much with comprehension. Batty (2015) and Ockey (2007) further claimed only half of the test takers found that the visual were helpful, whereby the rest found videos as a distraction.

\subsection{The Use of Video media in Listening Assessment}

Back in 1997, Gruba introduced the term 'video media' and thus highlighted the positive effects of using video media as a tool of assessing language learners' listening skills, despite many challenges and resistance from the language assessor. He emphasised the use of movies for second language instruction which has started in the 1930s, where Disney Studios' production produced a film specifically for non-native speakers of English. Since then, a lot of research has been conducted to examine the effectiveness of using video media as a tool in assessing listening skills. Recent studies have shown that the use of video media in listening assessment has been proven to elevate the students' performance in listening assessment. Mirvan (2013) in his study affirmed that the use of video in the classroom has given a big impact to the students in terms of motivation and participation due to the real life situation portrayed in the video used. This is due to the fact that video provides natural, meaningful, and authentic context for the learners to learn better.

Another finding by Woottipong (2014), Khoshsima and Izadi (2014) and Martinez (2010) also highlighted the positive reaction from the participants who feel that they were more interested in learning the language with the aid of videos as teaching materials. Besides, his findings revealed that their performances were better by using 
video media than using audio only as their listening assessment material. The research conducted by Memarzadeh and Shariati (2015) on second language learners also showed a significant difference in the students' score for the groups using video media as their listening assessment method. Video has been used as a tool to cater the needs of 21 st century learners as these learners are exposed with a lot of visual materials in their daily life. Technology has made it happen since learners nowadays are attached to the current technology used and thus learn faster with the aid of these tools.

\section{Method}

A quantitative approach has been utilised to obtain the data for the current study. There are four major groups of undergraduates from different faculties of University $M$ that have been selected as the samples. The students were non-English major but were taking English proficiency paper that focuses on listening. In this research, the participants were semester one Diploma students from FITA, FSSR, FMu, and FAD. Overall, random sampling was conducted to choose 150 students for this study.VAK questionnaire was first distributed to identify the students' learning styles. Next, they were given two sets of the same listening assessments. Multiple-Choice Question (MCQ) sheet was used as the instruments for this study. Multiple Choice Question (MCQ) sheet consists of three parts;

Part A: Yuna's Interview - iHeartradio Station,

Part B: Dato' Nicol Ann David's Interview

Part C: JK Rowling's Interview.

Five multiple-choice questions were provided for each video, respectively. After that, the questionnaire which consists of 26 questions was distributed.

Pre and post-test were used to collect the data of this study. Firstly, the students listened to the three audios selected and they were given 15 Multiple Choice Questions. This assessment was given early in the beginning of the semester (pre-test). Next, the students were given the same set of listening assessment at the end of the semester (post-test). In the post-test, students were required to listen and watch the videos while answering the questions.

Question papers were collected after the session. Next, students' results were calculated and analysed by using Statistical Package for the Social Sciences (SPSS). Inferential statistics was conducted and mean, standard deviation, and paired-sample t-test were used to analyse the data.

\section{Results}

Table 1. Paired-Sample t-test

\begin{tabular}{llllll}
\hline Faculties & & Mean & $\mathrm{N}$ & Std. Deviation & Std. Error Mean \\
\hline \multirow{2}{*}{ FiTA } & Audio Only & 9.938 & 32 & 2.564 & .453 \\
& Video Media & 10.500 & 32 & 2.436 & .431 \\
FSSR & Audio Only & 9.924 & 46 & 2.248 & .332 \\
& Video Media & 11.163 & 46 & 2.022 & .298 \\
FMu & Audio Only & 9.675 & 20 & 2.041 & .456 \\
& Video Media & 10.875 & 20 & 2.828 & .632 \\
FAD & Audio Only & 10.893 & 14 & 1.571 & .419 \\
& Video Media & 12.571 & 14 & 1.567 & .418 \\
\hline
\end{tabular}


Table 2. Paired-Sample t-test

\begin{tabular}{|c|c|c|c|c|c|c|c|}
\hline \multirow[t]{2}{*}{ Faculties } & & & \multicolumn{2}{|c|}{ Paired Differences } & \multirow[t]{2}{*}{$\mathrm{t}$} & \multirow[t]{2}{*}{ df } & \multirow[t]{2}{*}{ Sig. (2-tailed) } \\
\hline & & & Mean & Std. Deviation & & & \\
\hline \multicolumn{8}{|l|}{ FiTA } \\
\hline & Pair 1 & Audio - Video & -.563 & 1.958 & -1.625 & 31 & .114 \\
\hline FSSR & Pair 1 & Audio - Video & -1.239 & 1.639 & -5.128 & 45 & .000 \\
\hline $\mathrm{FMu}$ & Pair 1 & Audio - Video & -1.200 & 1.673 & -3.207 & 19 & .005 \\
\hline FAD & Pair 1 & Audio - Video & -1.679 & 1.154 & -5.444 & 13 & .000 \\
\hline
\end{tabular}

Based on Table 1 and 2, a paired sample t-test was conducted to compare the mean scores of students' results, between using audio only and video media methods. For FiTA, there is no significant difference in the mean scores for audio only method $(M=9.938 . S D=2.564)$ and video media method $(M=10.500, S D=2.436)$ listening assessment; $\mathrm{t}(31)=-1.625, \mathrm{p}=.114$. These results suggest that FiTA students performed equally the same using either audio only method or video media method and there is just a slight difference in the mean scores. Apart from that, for FSSR, FMu and FAD, Table 1 and 2 show that a paired sample t-test was conducted and there are significant differences between audio only method and video media method. A paired sample t-test indicated that mean scores of students' results for FSSR were significantly higher for video media method $(\mathrm{M}=11.163$, $\mathrm{SD}=2.022)$ than audio only method $(\mathrm{M}=9.924, \mathrm{SD}=2.248), \mathrm{t}(45)=-5.128, \mathrm{p}=.000, \mathrm{~d}=1.239$. Next, the results show that the mean scores obtained by FMu students for audio only method is $(\mathrm{M}=9.675, \mathrm{SD}=2.041)$ and for video media method is $(\mathrm{M}=10.875, \mathrm{SD}=2.828)$ at the level of significance $(\mathrm{t}=-3.207, \mathrm{df}=19, \mathrm{p}=.005)$. Lastly, a paired sample t-test was also conducted to compare the mean scores in audio only method and video media method. Hence, for FAD, there was also a significant difference in the mean scores between audio only method $(\mathrm{M}=10.893, \mathrm{SD}=1.571)$ and video media method $(\mathrm{M}=12.571, \mathrm{SD}=1.567)$ listening assessment; $\mathrm{t}(13)=-5.444$, $\mathrm{p}=0.000, \mathrm{~d}=1.678$. Thus, these results advocate that students perform better by using video media method compared to audio only method for FSSR, FMu and FAD.

\section{Discussion}

Based on the results above, it can be seen that there were students who performed better by using video media method and it was significant. In other words, students needed help when they sat for their listening assessment and by showing the videos; these helped them to have a better understanding. This result is in accordance to a study done by Khoshsima and Izadi (2014). In their study, it was found that students who were guided by their instructor and with prompts performed better compared to students who answered the questions without any help The results of this study are also parallel to a study done by Martinez (2010) and Woottipong (2014) where students' comprehension increased by using video and this would help them to perform better in their listening assessment. On this ground, video has the visual elements which are equivalent to students' learning styles. However, there were students who performed better in listening assessment by using audio only method. This is corresponding to a study done by Başal, Gülözer and Demir (2015) where students performed better by using audio only method compared to video media method. Apart from that, the results also indicated that there is no difference between the two listening assessment methods which are comparable to a study done by Batty (2015). In the study, it was mentioned that using video did not give much effect on students' listening comprehension.

\section{Conclusion}

Based on the students' results, their performances were found to be significantly different in the two tests. The majority of the participants performed better in video media assessment as compared to audio only assessment. It is proven that the use of video as a tool of assessment can greatly help students in their listening performance. The assessment is a tool to give authentic scenario for the students to practice for work. Therefore, an assessment must reflect the real life situation. Constant exposure to the natural conversation is needed to help the students to have better understanding in the assessment. According to the lecturers' observation, these students were given even more challenging tasks in their respective courses where the use of visual is commonly applied. This strengthens the fact that authentic and functional listening material assessment is necessary to be in line with the students' level of thinking and thus can spur their motivation to learn. Hence, why English subject still binds with the traditional method? There is a need for improvement in the ways of assessing students in order to test their actual ability in this 21 st century era. The advancement of technology has given a huge impact to the learners in their learning process and thus, the instructors have to be alert with this change in order to keep up 
with the current learning styles

\section{Recommendation}

The aim of language learning is that the students are able to make use of the target language not just in the classroom but also in the real world. However, if the students are accustomed to non-natural materials from the very start, the purpose of learning cannot be achieved. Educators are advised to venture into more authentic texts and materials (e.g., video and film, radio broadcasts, television programs) at all levels of L2 language instruction in the attempt to involve students in activities that reflect 'real-life' listening contexts. The aim to see the relevance of classroom activity that meets students' long-term listening goals could be a reality if students are more engaged in real -world tasks and authentic language Furthermore, when students listen to authentic materials, it serves as a useful practice for students to grasp the idea of the information without particularly comprehending every word or structure being heard. With this being said, it is hoped that educators and curriculum developers would consider using authentic materials when it comes to teaching listening and assessing listening skills in L2 classrooms.

\section{Acknowledgments}

We would like to thank our educational institution for supporting us financially through the ARAS Grant. We would also like to thank our team members and colleagues who have given us a lot of advice and feedback in completing this paper.

\section{References}

Armium, N., \& Rahmatian, R. (2011). The Effectiveness of Audio and Video Documents in Developing Listening Comprehension Skill in a Foreign Language. International Journal of English Linguistics, 118.

Arono. (2014). Improving Students Listening Skill through Interactive Multimedia in Indonesia. Journal of Language Teaching and Research. https://doi.org/10.4304/j1tr.5.1.63-69

Başal, A., Gülözer, K., \& Demir, İ. (2015). Use of Video and Audio Texts in EFL Listening Test. Journal of Education and Training Studies, 83-89. https://doi.org/10.11114/jets.v3i6.1001

Batty, A. O. (2015). A Comparison of Video- And Audio-Mediated Listening Tests with Many-Facet Rasch Modeling and Differential Distractor Functioning. Language Testing, 3-20. https://doi.org/10.1177/0265532214531254

Bejar, I., Douglas, D., Jamieson, J., Nissan, S., \& Turner, J. (2000). TOEFL 2000 listening framework: A working paper (TOEFL Monograph Series Report No. 19). Princeton, NJ: Educational Testing Service.

Goh, C., \& Taib, Y. (2006). Metacognitive instruction in listening for young learners. ELT Journal, 60(3), 222-232. https://doi.org/10.1093/elt/ccl002

Gruba, P. (1993). A comparison study of audio and video in language testing. JALT Journal, 15, 85-88.

Gruba, P. (1997). The Role of Video Media In Listening Assessment. An International Journal of Educational Technology and Applied Linguistics, 335-345. https://doi.org/10.1016/s0346-251x(97)00026-2

Hamouda, A. (2013). An Investigation of Listening Comprehension Problems Encountered by Saudi Students in the EL Listening Classroom. International Journal of Academic Research in Progressive Education and Development, 113-155.

Kenning, M. J., \& Kenning, M. M.. (1984). An Introduction to Computer Assisted Language Teaching. London: Oxford University Press.

Khoshsima, H., \& Izadi, M. (2014). Dynamic Vs. Standard Assessment to Evaluate EFL Learners' Listening Comprehension. Iranian Journal of Applied Language Studies, 1-26.

Kirana, M. (2016). The Use of Audio Visual to Improve Listening. English Education Journal.

LaScotte, D. (2015). Listening in Context: Incorporating Strategy Instruction in L2 Listening Practice. Minnetesol Journal.

Londe, Z. C. (2009). The Effects of Video Media in English as a Second Language Listening Comprehension Tests. Issues in Applied Linguistics, 41-50.

Macwan, H. (2015). Using visual aids as authentic material in ESL classrooms. Research Journal of English Language and Literature (RJELAL)

Martinez, R. G. (2010). Effects on teaching Listening Skills Through Videos to Advanced Students From The 
Foreign Language Department at The University of El Salvador During The First Semester 2010 (Published doctoral dissertation). University of El Savador, Central America.

Memarzadeh, M., \& Shariati, M. (2015). Video Clips Used as an Assessment Tool in Listening Placement Tests. International Journal of English Language Teaching, 3(8), 56-70.

Meskill, C. (1996). Listening Skills Development through Multimedia. Journal of Eductional Multimedia and Hypermedia.

Mirvan, X. (2013). The advantages of using films to enhance student's reading skills in the EFL classroom. Journal of Education and Practice, 4(13), 62-66.

Ockey, G. (2007). Construct implication of including still image or video in computer-based listening tests. Language Testing, 24, 517-537. https://doi.org/10.1177/0265532207080771

Richards, C., \& Dolati, R. (2011). Harnessing the Use of Visual Learning Aids in the English Language Classroom. Arab World English Journal.

Siegel, J. (2015). Research involving L2 listening instruction and instructors. ELT Journal. https://doi.org/10.1093/elt/ccv014

The British Council, The British Council 'The British Council Annual Report 1980/81', (London, The British Council, 1981), p. 22.

Vandergrift, L. (1999). Facilitating Second Language Listening Comprehension: Acquiring Successful Strategies. ELT Journal, 168-76. https://doi.org/10.1093/elt/53.3.168

Vandergrift, L., \& Tafaghodtari, M. H. (2010). Teaching L2 Learners How to Listen Does Make a Difference: An Empirical Study. Language Learning, 60, 470-497. https://doi.org/10.1111/j.1467-9922.2009.00559.x

Wang. J., \& Liu, W. (2013). English Listening Teaching Method Based on Multimedia. In Wenjiang Du, Informatics and Management Science, 337-342. China: Springer London. https://doi.org/10.1007/978-1-4471-4796-1_43

Wenden, A. (1986). What do second language learners know about their language learning? A second look at retrospective account. Applied Linguistics. https://doi.org/10.1093/applin/7.2.186

Woottipong, K. (2014). Effect of Using Video Materials in the Teaching of Listening Skills for University Students. International Journal of Linguistics, 6(4), 200-212. https://doi.org/10.5296/ijl.v6i4.5870

Yousefinia, E. (2012). The Effect of Self-Regulated Strategy Development Instruction On The Listening Performance Of Iranian EFL Learners.

\section{Copyrights}

Copyright for this article is retained by the author(s), with first publication rights granted to the journal.

This is an open-access article distributed under the terms and conditions of the Creative Commons Attribution license (http://creativecommons.org/licenses/by/4.0/). 